\title{
Intersections of Literature and Ethnography in the United States
}

\author{
Dominika Ferens
}

DOI: 10.21104/CL.2016.3.03

\begin{abstract}
This article argues for the need of a rapprochement between scholars who study ethnographic and literary ways of knowing minority communities that have limited access to self-representation. While in the past literary critics and cultural anthropologists tended to emphasize their distinctive methodologies and conventions of writing about such communities, this article draws on the work of postmodern anthropologists, critical theorists, literary critics, and historians to demarcate the common ground between ethnography and literature. Through the efforts of Clifford Geertz, James Clifford, Mary Louise Pratt, George Marcus, Michael Fisher, and many others, cultural anthropology has, at least to some extent, come to terms with the limitations of participant observation and the textuality of its product. However, a parallel reckoning has not taken place within literary studies. It is the goal of this article to push the process a step further by emphasizing the mutual indebtedness of literary and ethnographic writing.
\end{abstract}

Keywords ethnography, autoethnography, literature, knowledge, cultural patterns, singularity.

The present paper is a revised version of sections of my study Ways of Knowing Small Places: Intersections of American Literature and Ethnography since the 1960s (Wydawnictwo Uniwersytetu Wrocławskiego, 2010).

Contact dr hab. Dominika Ferens, prof. UWr, Institute of English Studies, University of Wroclaw, ul. Kuźnicza 22, 50-138 Wroclaw, Poland; e-mail: dferens@poczta.onet.pl.

Jak citovat / How to cite Ferens, Dominika. (2016). Intersections of Literature and Ethnography in the United States. Český lid 103, 371-394. doi:http:// dx.doi.org/10.21104/CL.2016.3.03 
Back in the mid-1960s I decided to follow my BA in literature with a PhD in anthropology. In my first graduate class a classmate asked our famous teacher, a woman who had done ground breaking work in African ethnography, what she saw as the difference between an ethnography and a novel. The teacher answered brusquely, with impatience and disdain: 'If you don't know that, you don't belong here.' My classmate dropped out after the first quarter, became a leader in the anti-war movement, and cofounded the women's liberation movement on the West Coast. The teacher retired. I have gone on to spend more than thirty years pondering the differences between the ethnography and the novel. Janet Tallman, 'The Ethnographic Novel' (2002: 10).

Ethnography and literature inhabit a continuum but, as a rule, neither likes to be mistaken for the other. At the far ends of the continuum there are staunch purists who draw sharp boundaries around their own practices. One group of purists set up its camp at the end of the nineteenth century, when anthropology became an academic discipline and its practitioners ${ }^{1}$ defined themselves in contrast to 'amateurs': travel-writers, missionaries, and regionalist writers. The pure literature camp dates back to the 1930s and 1940s, when New Critics began to insist on literature's uniqueness, distinctiveness, and oppositionality to other cultural discourses. ${ }^{2}$ Playing in the muddy middle ground between the two camps are those who encroach on each other's territory, either because they refuse to see the difference, or because they object to the way that difference is constructed. They are often writers who have used literary

1 Franz Boas, one of the founding fathers of American anthropology, warned his students and colleagues about the dangers of collapsing lay and professional ethnography: "The greater the public interest in a science and the less technical knowledge it appears to require, the greater is the danger that meetings may assume the characteristics of popular lectures. Anthropology is one of the sciences in which this danger is ever imminent, in which for this reason, great care must be taken to protect the purely scientific interest." (Franz Boas qtd. in Stocking 1992: 8) As the epigraph from Janet Tallman's 'The Ethnographic Novel' suggests, in the 1960s the gulf between legitimate academic discourse and fiction was still felt to be very wide. Maintaining the distinction is in the interest of university-based anthropologists to this day.

2 Though it was the formalists who first insisted on keeping literature pure, more recently some minority writers have followed suit. They occasionally invoke the 'pure literature' ethos in self defense, feeling constrained as much by those who hold them accountable for representing their minorities as by those who appreciate them more for the authenticity and ethnographic accuracy of their work than for its artistry. Among the authors who have attempted to shake off the burden of ethnic representation are Mei-mei Berssenbrugge, Li-Young Lee, and David Wong Louie (see interviews in King-Kok Cheung, Words Matter, 2000). When in 1998 LoisAnn Yamanaka's Association for Asian American Studies prize for literature was revoked due to protests that Yamanaka consistently vilified Filipinos in her writing, 82 Asian American writers wrote letters in her defense, insisting that fiction writers, unlike social scientists, have poetic license and are answerable to no-one for their racial and ethnic representations (see Huang and Nelson 2003: 321). Conversely, Frank Chin attempted to discredit Maxine Hong Kingston by accusing her of writing 'pop cultural anthropology' (Kim 1982: 198). 
discourse as a way to expose the fictions of social science; undisciplined anthropologists who have provisionally abandoned the conventions of objective reporting for the more subjective genres of autobiography or fiction; as well as members of minority groups traditionally objectified by ethnography, who have usurped the power of representation to produce counter-discourses.

This account of the intersection of ethnography and literature begins the 1960s because of the decade's watershed status. With decolonization gaining momentum abroad and the Civil Rights movement in the United States, the question of who had the right to represent whom (in politics, science, the arts, and literature) became a highly charged one. The Vietnam War, various strands of feminism, as well as the succession of homophile, gay, lesbian, and queer movements cross-fertilized each other and politicized unprecedented numbers of people. When the 1965 Immigration Act replaced legislation that privileged European immigration, large numbers of immigrants from Third World countries began to enter the United States. The ensuing demographic changes strengthened minority groups' resolve to challenge the white hegemony. Assimilation to the white middle-class norm came to be seen by many as gratuitous self-effacement; ethnic difference could be claimed as a badge of distinction, even though the racial hierarchy remained largely intact.

Until the late nineteenth century, writing about people of color was the preserve of white travel writers, and, since then, anthropologists or sociologists. Few Americans of color had access to the social sciences and any literature they wrote was subject to market pressures. In the 1960s, however, non-traditional students - people of color and women - began entering universities in large numbers. The first ethnic studies programs were instituted at San Francisco State University in 1968, and at UC Berkeley and UCLA in 1969, in the wake of mass student strikes; other campuses followed. Whether they did graduate research in the social sciences or studied literature and creative writing, the former objects of ethnography began to develop new discursive and formal ways of intervening in, distorting, and playing with the tradition of ethnographic representation. These ranged from auto-ethnography (representing oneself and one's own group) to counter- and mock-ethnography (turning the tables on the dominant group and submitting it to ethnographic scrutiny), as well as anti-ethnography (refusing to play the ethnographic game at all). Women's and minority literatures grew strong; 'representative' texts were reluctantly added to college reading lists as a result of periodic canon wars.

In the words of historian James Clifford, the realization that anthropology is "enmeshed in a world of enduring and changing power inequalities" and "no longer speaks with automatic authority" brought on a disciplinary crise de conscience (Clifford 1986: 9). Symptomatically of these developments, in 1986 anthropologist Michael J. Fischer surveyed the existing body of ethnic American fiction and concluded his 40-page essay with the observation that, in a sense, his discipline had been upstaged. He was not the first anthropologist 
to take literature by people of color seriously: ethnic literature courses were taught at the Chicago School of Sociology ${ }^{3}$ long before they became a staple at English departments (Capetti 1993: 31). But while the Chicago ethnographers read ethnic fiction as primary material for investigation, Fischer combed it for methodological and formal insights:

Just as the travel account and the ethnography served as forms for explorations of the 'primitive' world [...] and the realist novel served as a form for explorations of bourgeois manners and the self in early industrial society, so ethnic autobiography and autobiographical fiction can perhaps serve as key forms for explorations of pluralist, post-industrial, late twentieth-century society. (Fischer 1986: 195)

Certainly, anthropology departments did not shut down overnight at this announcement; nor did most practitioners of the discipline come to believe that the methods and procedures elaborated for the study of cultures had become obsolete. Yet Fischer's assessment did signal the growing awareness among American anthropologists that the tools of their trade were inadequate for dealing with cultures and peoples that had long ago become detached from places and that refused to keep still for observation.

The very titles of well-known post-1960 publications in anthropology and sociology - Reinventing Anthropology; The Death of White Sociology; Decolonizing Methodologies: Research and Indigenous Peoples; Anthropology as Cultural Critique; Writing Culture: The Poetics and Politics of Ethnography; Women Writing Culture - show how the social sciences repeatedly attempted to shed their old skins and adjust to new sociopolitical contexts. Some scholars retrenched and sought ever more rigorous scientific standards; others tentatively took up unconventional tools and genres, including autobiography and ethnographic fiction as modes of self-reflection and reevaluation of their discipline. Autobiography and fiction were a means to continue cross-cultural investigation on new terms, without the authority that comes with doing science. Many shifted their interest to communities within the United States, such as primarily white rural and mining towns, food cooperatives, New-Age health centers, or urban ghettoes. ${ }^{4}$ As cultural anthropology lost its foothold in the Third World and fewer graduate students could do their apprentice-

Carla Capetti observed: "At a time when literature courses in English departments ended with the seventeenth century and American literature, African American literature, ethnic literature, although they were read, were not considered worthy of critical attention, Chicago sociologists acted to constitute, preserve, and promote them." The knowledge produced by the sociologists is highly problematic, having been generated "for the purpose of social control," but the legitimation of minority writers by the Chicago sociologists needs to be acknowledged (Capetti 1993: 31). 
ship abroad, enrolments fell. ${ }^{5}$ At least some of those who might have become social scientists dropped out and studied English or creative writing, including Paule Marshall and Russell Leong who went on to have distinguished careers in literature. Hundreds of others took heart from the successes of Alice Walker, Toni Morrison, Maxine Hong Kingston, and Leslie Marmon Silko and attempted to write for a living.

Meanwhile, the humanities and social sciences absorbed the critical theories of Jacques Derrida, Louis Althusser, Michel Foucault, Pierre Bourdieu, as well as those of feminist philosophers who challenged the dominant epistemological assumptions, including Nancy Hartsock, Sandra Harding, and Donna Haraway. Literary critic Ryszard Nycz views the ensuing decades as a period marked, on the one hand, by the process of aestheticization of the cultural reality and the tendency to read culture as text, and, on the other, by the "'reculturation' (contextualization) of literature which thus becomes once again one of the discursive practices of the cultural reality" (Nycz 2006: 31, my translation).

Reflecting in 1986 on these historical and theoretical developments, Clifford reached for powerful geographical metaphors: "A conceptual shift, 'tectonic' in its implications, has taken place. We ground things, now, on a moving earth. There is no longer any place of overview (mountaintop) from which to map human ways of life, no Archimedean point from which to represent the world. Mountains are in constant motion. So are islands: for one cannot occupy, unambiguously, a bounded cultural world from which to journey out and analyze other cultures." (Clifford - Marcus 1986: 22)

Significantly, islands have been among the key sites for the development of Western academic methods and procedures for the systematic study of nonwestern peoples. Professional anthropologists in the early twentieth century traveled out to islands which they understood as equivalents of biologists' laboratories - perfect preserves of the 'primitive', offering the greatest possible contrast for the 'modern'. In effect, cultures came to be perceived as confined to small places, unchanging, and immobile. ${ }^{6}$ Until the atrocities of World War II provided evidence to the contrary, ethnography tended to support the evolutionary paradigm in which culture was unitary and Western peoples stood at

5 See for example Keesing and Keesing's New Perspectives in Cultural Anthropology (1971) and Messerschmidt's "Introduction" to Anthropologists at Home (1981).

6 In 'Putting Hierarchy in its Place' Arjun Appadurai problematized the fact that for traditional ethnography "natives are not only persons who are from certain places, and belong to those places, but they are also those who are somehow incarcerated, or confined, in those places" while anthropologists think of themselves as mobile and unattached to any particular place (Appadurai 1988: 37). James Clifford's 1997 study Routes: Travel and Translation in the Late Twentieth Century elaborated on this problem, trying to imagine an ethnographic practice that disrupts the old paradigm. James Buzard, in turn, pointed out in his 2003 essay 'On Auto-Ethnographic Authority' that 'native-' or auto-ethnographers tend to unwittingly perpetuate the image of their ethnic groups as confined to small places in order to build up their own authority to represent those groups. 
the apex (although functionalism, patterns of culture anthropology, and configurationism offered less teleological alternatives). For instance, in order to better understand the problems of American adolescents Margaret Mead did not go "to Germany or to Russia, but to Samoa, a South Sea island about thirteen degrees from the Equator" because, as she explained,

we do not choose a simple peasant community in Europe or an isolated, group of mountain whites in the American South, for these people's ways of life, though simple, belong essentially to the historical tradition to which the complex parts of European or American civilisation belong. Instead, we choose primitive groups who have had thousands of years of historical development along completely different lines from our own, whose language does not possess our Indo-European categories, whose religious ideas are of a different nature, whose social organisation is not only simpler but very different from our own. From these contrasts, which are vivid enough to startle, and enlighten those accustomed to our own way of life and simple enough to be grasped quickly, it is possible to learn many things about the effect of a civilisation upon the individuals within it. (Mead 1973: 5)

For decades, Pacific, Caribbean, and other islands were the preferred sites of ethnographic research, though fieldwork was also done in Africa, Central and South America, Australia, as well as Alaska. But the island study remained paradigmatic, and scholars continued to seek small, culturally homogenous communities that had had as few contacts as possible with Western culture. Pacific islanders, Caribbeans, and others were in no position to reciprocate. As Sandra Harding pointed out, in the nineteenth-century "the chances were low that aborigines would arrive in Paris, London, and Berlin to study and report back to their own cultures the bizarre beliefs and behaviors that constituted the 'tribal life' of European anthropologists" (Harding 1991: 155). Colonial migrations of white people to the Third World precipitated reverse migrations of Third World peoples to the metropolis in the twentieth century. Over time, the migrants and their descendants have attempted to alter the asymmetries in access to textual representation, political power, and economic resources.

Fictional narratives set on faraway islands are especially prone to being read ethnographically. Whether depicted as utopia, South Sea paradise, desert island, or relic of the stone age, home to devious sirens, noble savages, cannibals, or lusty maidens, the island is the locus of essential difference, sedimented with layers of western cultural associations. ${ }^{7}$ Separate and clearly 
bounded, it once seemed to be all of one thing, graspable, legible, stable, and unchanging. Some early anthropologists treated islands as laboratories or time machines that could bring one face to face with the prehistory of 'western civilization'. Yet in order to treat islands as pristine, insulated laboratories, ethnographers had to ignore the often complex history of intercultural contacts before their arrival, as well as their own contaminating presence in the field. Their mission was to 'salvage' for safekeeping in Western archives written records of cultures supposedly doomed to extinction - cultures valuable and interesting precisely because they would soon become extinct or altered through contact with modernity. ${ }^{8}$

The fact of writing from or about islands and other small places for publication in the American metropolis induces authors to take into account reader interests and expectations that may be very different from those of people in the small, geographically remote places, or in immigrant communities in the United States. In recent decades, the mainstream American interest in such places has been molded by multiculturalism. As an educational policy and a signal to all Americans that they should expose themselves to 'ethnic' difference, multiculturalism encourages readers to sample literature about small places much as they sample kimchi, baked yams, or bakhlava. One literary voice usually stands for one minority on the school or college reading list, just as in traditional anthropology one monograph per island or tribe sufficed. As a rule, experimental and non-narrative writers are not seen as 'representative', hence the preference of fiction over poetry.

Admittedly, much canonical American literature can also be said to be about 'small places'. Places of ethnographic interest need not necessarily be geographical islands inhabited by people of color. Other differences may also have exotic appeal. For instance, Edith Wharton turned New York's upper class into an object of ethnography, encouraged by Henry James to "do New York" (James qtd. in Bentley 1995: 2), that is, to investigate the customs and manners of the tribe she knew best. ${ }^{9}$ But when the subject, object, and intended audience of ethnography are all white and (upper) middle class, the asymmetry of power is erased. Had Wharton's 'natives' found her representations wanting, they could have published their own competing fictions. In fact, many such fictions were already in circulation at the time. Similarly, Sherwood Anderson's or Don DeLillo's narratives of small places appeared in the literary

8 See for example: Johannes Fabian, Time and the Other (1983); Marianna Torgovnick, Gone Primitive (1990). For ethnography as 'salvage' see James Clifford's article The Others: Beyond Salvage Paradigm (1989).

9 Nancy Bentley produced a detailed analysis of Edith Wharton's work as a mode of ethnography of New York's leisure class. As Bentley explained: “In my study, understanding fiction [...] means understanding what it is to do fiction, what kind of social and aesthetic office it performs. To analyze fiction as a practice, as a way of mastering manners on the page, I explore convergences between novels and ethnographic texts and their collaboration in helping to produce our modern discourse of culture. In turn, the collaboration opens up for us new historical and critical perspectives on the particular mastery of manners that is fiction writing" (Bentley 1995: 2-3). 
marketplace alongside hundreds of competing representations of white middle-America. So many variants of Winesburg, Ohio and The-College-on-the-Hill exist in print that to treat these representations as a source of ethnographic knowledge about Euro-Americans seems absurd. Yet fictions by Americans of color who were among the first of their minorities to achieve recognition Sui Sin Far, Zora Neale Hurston, Richard Wright, N. Scott Momaday, Maxine Hong Kingston, or Rodolfo Anaya - did bear the burden of ethnographic representation. ${ }^{10}$ They were appreciated primarily (though not solely) because they transported readers to places they avoided in real life and rarely saw mentioned in print: the ghetto, the reservation, Chinatown, the all-black town, or the barrio. Over the years, these and other authors of color put countless texts into circulation; through exposure to different techniques of representation readers increasingly began to pay attention to point of view, voice, narrative technique, use of irony, parody, and other formal strategies. However, that which literary critic King-Kok Cheung calls a "strong 'ethnic' quotient" (Cheung 2000: 19), remains a magnet for mainstream American readers. Small places are always read as 'particular' and cannot aspire to 'universality' in a way that Winesburg, Ohio or The-College-on-the-Hill can. ${ }^{11}$ The asymmetry between small places and big places in terms of political as well as literary representation persists.

Ethnography (whether in the form of travel narrative, fiction, or monograph) is an intertext of many American fictions. Thus one reason for building an awareness of the goals, methods, and key concerns of ethnography is that when studying literary texts we can then trace certain persistent themes, discursive tensions, and formal innovations that would otherwise go unnoticed. Another reason for drawing on the work of historians and critics of ethnography is that they have theorized "ways of knowing" more systematically than have literary theorists, due to the epistemological crisis in the social sciences. If, as I am trying to suggest, literary representations of racial/cultural difference are often read ethnographically, then the insights developed within the social sciences might be helpful for problematizing minority literatures' relation to knowledge.

Several Polish literature scholars - most notably Michał Paweł Markowski, Ryszard Nycz, Andrzej Mencwel, Anna Łebkowska, and Anna Burzyńska have, in recent years, explored the intersection of literary studies and anthropology, inspired (or provoked) by such postmodern theorists as Clifford Geertz, Richard Rorty, and Jacques Derrida, the reader-response theorists Stanley Fish and Wolfgang Iser, the Birmingham School, as well as feminist theories.

10 In Edith and Winnifred Eaton: Chinatown Missions and Japanese Romances (Ferens 2002) I wrote extensively about mainstream American readers' insistence on reading Sui Sin Far's fictions as ethnographic accounts. There is ample evidence that the same holds true for much fiction by writers of color today. 
The 'cultural theory of literature' proposed by Nycz, as well as his valorization of 'transdisciplinarity', give me license to think about the problems that emerge when literature acts like ethnography, or is mistaken for ethnography, or when ethnography acts like literature. But due to the virtual absence of the problem of racial representation in Polish scholarship, and the search for theories that might revitalize the study of mainstream Polish literature, these approaches have limited relevance for this project. To my best knowledge, the only Polish Americanist to have explored the intersection of literature and ethnography is Agata Preiss-Smith. Yet in view of the rapidly changing racial demographics in Eastern/Central Europe, neither ethnography nor literature can continue to ignore the category of race.

A brief overview of the two types of writing (and ways of knowing) should make apparent the points at which they intersect and diverge. An ethnography is generally understood to be an academic text based on a "research process in which the anthropologist closely observes, records, and engages in the daily life of another culture" in order to make his or her "personal and theoretical reflections available to professionals and other readerships" (Marcus - Fischer 1986: 17-18). A physical distance and knowledge gap between the objects and readers of traditional ethnography is a precondition for its existence. The ethnographer acts as a go-between, with privileged access to places few of his or her readers are likely to ever visit. Bronisław Malinowski is credited with having established fieldwork through 'participant observation' in a faraway place as a rite of passage for anthropologists when he returned from Melanesia to the London School of Economics after World War I. In the introduction to Argonauts of the Western Pacific Malinowski defined the face-to-face encounter with the other, and the attempt to 'grasp' the other's culture, as a moral imperative for the serious scholar: "The Ethnographer has in the field [...] the duty before him of drawing up all the rules and regularities of tribal life; all that is permanent and fixed; of giving an anatomy of their culture, of depicting the constitution of their society” (Malinowski 1984: 11). 'Grasping' the exotic culture and 'getting the news out' (Graham Watson qtd. in Wolf 1992: 1) became the secular mission of British and American ethnographers who hoped such knowledge would open the Western self to the enriching influence of other cultures and provide reference points for rethinking Western culture. What ethnography might do to or for the people it investigated was of marginal concern. Even when the motive was 'salvaging' premodern cultures from the steam-roller of modernity, ethnographers imagined Western audiences - not the indigenous peoples - as the beneficiaries. As late as 1968, Hortense Powdermaker asserted: "The anthropologist is not primarily interested in helping his informants, although he may do so inadvertently. His motivation is to secure data." (1966: 296)

This way of imagining the relation between the subjects and objects of ethnography collapsed when the newly decolonized peoples on the one hand, and feminists and Americans of color on the other, refused to play their appointed 
roles. 12 "How removed my fieldwork was from the fieldwork out of which modern anthropology was born," wrote the Cuban-Jewish American Ruth Behar, "the sort of fieldwork where one retired to the most distant village one could find, or stranded oneself on an island and took the heroic role of ethnographer, towering over all the outsiders and elites out of a sense of higher calling." (1996: 243) Likewise, Pnina Motzafi-Haller, an Israeli of Mizrahi origins trained in the U. S., found herself looking for ways to avoid "essentializing my people' (1997: 215). “One's positioning within marginalized communities," she discovered, "shapes not only one's research interests and the epistemologies one chooses in developing such research; it also sensitizes one in conscious and/or unconscious ways to look at practices of exclusion and perhaps to write in ways that do not accept the status quo" (1997: 216). In the post Civil Rights era, the ethics of 'grasping' cultures became suspect, as did the goal of hoarding cultural knowledge in Western academia - a practice that disregarded the welfare of those under investigation, even as their existence on the margins of global capitalism became increasingly precarious.

Traditional British and American ethnographies were organized according to research topics or problems. In the nineteenth century, the research topics were systematized in the form of Notes and Queries on Anthropology, ${ }^{13}$ and periodically revised in response to current theoretical debates. Ethnographers were trained to look for cultural patterns and ignore singular events. "To pause for a moment before a quaint and singular fact; to be amused at it, and see its outward strangeness; to look at it as a curio and collect it into the museum of one's memory or into one's store of anecdotes," wrote Malinowski, "this attitude of mind has always been foreign and repugnant to me." (1984: 517) Expected to 'reduce the puzzlement' (Geertz qtd. in Wolf 1992: 128) by discovering cultural patterns, the ethnographer could not afford to be distracted by the singular.

As ethnographic description focused on typical behavior rather than on what the researcher saw someone doing on a particular occasion, the 'ethnographic present' was most commonly used. As Malinowski put it bluntly:

12 In his critical history of the Chicago School of Sociology's research on Asian Americans, Henry Yu demonstrates that in the first half of the twentieth century the non-white ethnographers and their informants did play their appointed roles (2001: 93-150). Anthropology students like Paul Siu, Rose Hum Lee, and Frank Miyamoto are among a host of minority researchers trained in the first half of the twentieth century, who duly studied their own immigrant communities. If they experienced the discomfort voiced by subsequent generations of scholars like Motzafi Haller and Behar, they did not feel entitled to voice it. The Japanese internees studied by Miyamoto (also an internee) during World War II were certainly in no position to object to the way Ruth Benedict used their statements to define Japanese culture as antithetical to American culture in every detail. See Geertz (1984: 102-128) for a fascinating analysis of Benedict's The Chrysanthemum and the Sword: Patterns of Japanese Culture.

13 The first edition of Notes and Queries was prepared by British anthropologists in 1874, to be used by non-professionals, including travelers, missionaries, or colonial administrators, for collecting ethnographic data. Notes and Queries consisted of a long list of question grouped under such topics as 'Physical Characteristics' and 'Language'. The last (sixth) edition came out in 1951. For a discussion of various editions of Notes and Queries, see Dan Rose (1993: 209-210). 
"we are not interested in what A or B may feel qua individuals, in the accidental course of their own personal experiences - we are only interested in what they feel and think qua members of a given community" (1984: 23). Even if one's professed goal was to report home 'how the natives think', textual authority and closure were achieved by demonstrating that one understands the 'natives' better than they understand themselves. Reflecting with wonderment on the structural-functionalist training she received decades earlier, Edith Turner wrote: "An apparently coherent picture [of a culture could] be obtained, based on many experiences, numerical surveys, and reported events. We could break down the material into the Environment, Subsistence, Social Structure, Kinship Rules, Economic Exchange, Religious Change, Conflict and Maladjustment.” (Turner 1993: 30) As these categories suggest, the body of the ethnographic text was expository but lacked temporal ordering. If the ethnographers felt compelled to write about their arrival in the field and how they came to know the local people, this information was confined to the introduction, postscript, or footnotes.

Since the 1980s, American ethnographers have concertedly labored to reinvent their discipline using insights from critical theory, cultural studies, ethnic studies, feminist theory, and queer theory. The enormous theoretical and methodological changes are evident when we survey the standard American and British cultural anthropology/ethnography textbooks published around 1960 and after. ${ }^{14}$ But though ethnography's axioms (including the irrelevance of singularity) have been modified, the discipline still seeks cultural patterns in everyday social interactions. ${ }^{15}$ Its main objective is, after all, "to reduce the puzzlement" and to discover "the informal logic of actual life" (Geertz qtd. in Wolf 1992: 128).

Like ethnography, literature can be understood as a mode of encountering otherness, whether the other is conceived as an unfamiliar culture, something closer to home but beyond the horizon of our intellectual or aesthetic experience, or an aspect of the self as yet unexplored. Where writers and readers draw the line between the familiar and unfamiliar depends as much on their cultural background, class, gender, race, and age as on their individual

14 See for example Felix M. Keesing, Cultural Anthropology: The Science of Custom (1958),

Roger M. Keesing and Felix M. Keesing, New Perspectives in Anthropology (1971); Richley H. Crapo, Cultural Anthropology: Understanding Ourselves and Others (1990); Harry F. Wolcott, Ethnography: A Way of Seeing (1999); and David M. Fetterman, Ethnography (1998). Writing in 1958, Keesing presented anthropology as a 'science' and focused largely on ThirdWorld cultures; by 1990, the idea of anthropology as a science had lost ground; true to its subtitle Understanding Ourselves and Others, Crapo's textbook provides numerous examples from Western culture to offset those from non-Western cultures. It foregrounds cultural adaptation and change, unlike earlier textbooks which favored premodern cultures.

15 'Pattern' is a key word for anthropologists. For instance, Ruth Benedict's bestknown works are titled Patterns of Culture and Chrysanthemum and the Sword: Patterns of Japanese Culture. Chapter 1 of Margery Wolf's Revolution Postponed: Women in Contemporary China is titled 'The Past and the Pattern'. 
exposure to literature. For instance, Derek Attridge invokes Jacques Derrida and Emmanuel Levinas to talk about literature's capacity to 'free up' "the settled patterns of my mental world, the norms of my idioculture" so that "the truly other finds a welcome". For Attridge, repeated exposure to the other through literature has the potential to alter subjectivity, until "the self can be said to be a 'creation of the other'" (2004: 24).

While self-consciously avant-garde literature is by definition about pushing both writer and reader beyond the safety of the known, popular fiction, too, can serve as a space of encounters with the other, as the following reminiscence by anthropologist Margery Wolf suggests:

When I was a girl growing up in a working-class family [...] I was particularly interested in novels about women. I read to find out about a life that I saw from a distance but to which I had no access. I knew the stories were often 'phony', but I didn't care. I wanted to know how women in cities boarded streetcars, bought food, chose friends, what they talked about, and so on. And I wanted to know from someone who was there, had experienced it. [...] I hungered for the details [such novels] provided me on a life that seemed exotic and exciting. In time, though, I gave up novels - there was no longer enough new information to make up for the boring stories. (Wolf 1992: 58-59)

Thus Wolf, a budding anthropologist, lost interest in the adult heroines of popular romances when she learned as much as she needed to perform the role of city woman and the heroines' otherness paled. The bulk of American literature is written in recognizable (often formulaic) genres. Although each of these genres in its own way mediates the encounter with the other, it nonetheless makes some form of encounter possible for some readers.

Exploring the distinction between academic and literary ways of knowing, Attridge draws on Levinas, who faulted educational methods grounded in Western philosophy for being "dedicated to the mastery of otherness, leaving no room for surprise; whereas for [Levinas], true philosophical understanding, and true teaching and learning can be achieved only in being surprised by the other" (Attridge 2004: 84). For Charles Bernstein, another close reader of Levinas, poetry is the ideal way of knowing, for it has an infinite capacity for surprise:

no single sentiment but clashes of sentience: the magnificent cacophony of different bodies making different sounds, as different as the hum of Hester Street from the gush of Grand Coulee, the buzz of Central Park on August afternoons from the shrieks of oil-coated birds in Prince William Sound (Bernstein 1992: 1). 
Bernstein believes that literature in general (and poetry in particular) leaves room for dissent, both formal and ideological, and for the multiplicity and indeterminacy of meaning. It works against "the male version of the universal voice of rationality trying to control, as if by ventriloquism, female bodies" (Bernstein 1992: 5). Poetry speaks in many voices, and, at its best, "include[s] multiple conflicting perspectives and types of language and styles" (Bernstein 1992: 2).

Like ethnography, fiction written at the interstices of cultures often engages in the production and interpretation of difference. Building on Benedict Anderson's theory of the novel's key role in the construction of national identities, Jonathan Culler draws attention to the "radically different ways in which readers of the novel may be both outsiders and insiders. In colonies or former colonies in particular, readers' ideas of national identity may arise from a vision from outside, when they see how they are placed on the map" (Culler 1999: 38). It is in the form of the novel and the possibilities it creates for (dis)identification, rather than in its representative function, that Culler sees the novel's potency:

What is distinctive about the novel, about its formal adumbration of the space of a community, is its open invitation to readers of different conditions to become insiders, even while the novel raises as a possibility the distinction between insider and outsider, friend and foe, that becomes the basis of political developments. (Culler 1999: 38)

Whereas ethnographers, to be treated seriously, must demonstrate full control of their field material by eradicating any loose ends and unresolved dilemmas, fiction writers habitually leave readers puzzled or unsettled. To write well means to occasionally relinquish control, abandon familiar language patterns, and avoid resolutions. Literature, particularly poetry, is averse to closure: "anything [is] better than the well-wrought epiphany of predictable measure - for at least the cracks and flaws and awkwardnesses show signs of life" (Bernstein 1992: 2). The novel, the play, and the poem encourage the mingling of many voices. As Mikhail Bakhtin observed, even an ideologically committed novel is dialogic and therefore polyvocal.

Paradoxically, however, in the words of Elisabeth Frost, "the importation of ethnography into the novel has impeded experimentation". The stress on the representational function of literature has deterred some authors from pursuing their formal interests while keeping those who did pursue them out of the multiethnic canon. Such was the case, Frost points out, of Theresa Hak Kyung Cha, author of Dictee (1982), a multigeneric, multilingual, and polyvocal book assembled out of the shards of many cultures. Because Cha failed to "assert an 'authentic' representative Korean American self, she was not embraced by the 
early critics". ${ }^{16}$ It is only in the last decade that she and other 'unrepresentative' minority writers have received the critical attention they deserve.

Ethnography describes typical behavior and 'common denominator people' (Van Maanen 1988: 49); by contrast, literature thrives on the singular, the eccentric, and the strange - that which cannot easily be explained away or reduced to a familiar pattern. Literature is generally more interested in what "A or B may feel qua individuals" (Malinowski 1984: 23) than in what they are culturally conditioned to feel; in fact, the novel only becomes interested in A and B when they pull slightly away from their cultures. Since the novel form is associated with the rise of capitalist ideology and the concomitant emergence of individualism, it tends to focus on singular characters, often in the process of identity formation, even when readers are expected to recognize some of the characters as types (like Hemingway's Robert Cohn, the alienated New York Jew). Fiction may have its equivalent of Notes and Queries in the form of implicit themes, but it is usually plot-driven and organized around developing characters. When fiction writers use the present tense, they usually do so to create a sense of immediacy, not to suspend characters in an ahistorical 'ethnographic present'.

I am not as optimistic as Attridge and Bernstein about literature's unique capacity to represent the other without ventriloquizing, or to free us from old patterns of thought and form. Literature that mediates between cultures is subject to particular pressures and misreadings. The pressures, as Vietnamese immigrant writer Le Ly Hayslip explains, come from having to reconcile "what people [in the U. S.] want, need to know, and what people should know about us. We offer something that they would not understand even though they may have lived [in Vietnam] as servicemen, journalists, politicians, and scientists” (Cheung 2000: 109).

Conversely, James Clifford's readings of Michel Leiris, Marcel Griaule, and Marjorie Shostak in Predicament of Culture (1988) suggest that ethnography too has its cracks and flaws that harbor life, and that formal innovation is possible within the limitations of an academic genre. Because ethnographers and fiction writers have often defined themselves in opposition to each other, it is easy to forget the traffic and cross-fertilization that has gone on between them. Anthropologists have been avid readers of fiction, particularly when working in the field, where books often replaced family and friends. Anthropologists have also written literature, whether to popularize their findings, or to release pent up memories of fieldwork that once had no place in formal ethnographies, or simply because they enjoyed cre-

16 I thank scholar and poet Elisabeth Frost for these insightful comments written in response to a draft of the present paper. 
ative writing. ${ }^{17}$ Conversely, creative writers are exposed to ethnography in a variety of popular forms, such as geography textbooks, ethnographic films, magazines, and travel guides.

The traditional model of ethnography relied on the existence of a knowledge gap and the technique of familiarizing the unfamiliar; now that many ethnographers do research 'at home' (in places that are relatively well known to their readers), the goal of their work is usually to make the familiar seem strange (and thus not inevitable, open to change). Early ethnic American literature, too, relied on the existence of a knowledge gap: it purported to represent to the 'mainstream' the experience of 'minority' groups. ${ }^{18}$ Today much of the 'mainstream' is non-white. 'Minority' communities themselves (which fifty years ago may have lacked both the resources to buy books and literacy skills) now constitute an important readership for ethnic fiction. Defamiliarizing the familiar, representing minority groups to themselves, and mapping out their relationships to other groups are now parallel concerns.

Ostensibly ethnography and literature relate very differently to the problem of knowledge. The former makes serious knowledge claims and must amass, sort, and interpret data to support them; aiming for objectivity, it must also constantly question its own underlying assumptions. By contrast, literature makes no claims to objectivity (though it cares profoundly about knowledge) and is therefore free to use any means to keep the reader engrossed in its fictions; singularity, partiality, and subjectivity are the measures of its strength - not weakness.

Some literary works double up as auto-ethnography or enter into a dialogue with ethnography. In Auto/Ethnography: Rewriting the Self and the Social (1997), anthropologist Deborah Reed-Danahay proposes a broad definition of auto-ethnography that covers three overlapping genres: 'native anthropology', in which people who were formerly the subjects of ethnography become the authors of studies of their own group; 'ethnic autobiography', personal narratives written by members of ethnic minority groups; and 'autobiographical ethnography', in which anthropologists interject personal experiences into

17 Ample evidence of anthropologists reading fiction can be found, for instance, in Bronisław Malinowski's Diary and Hortense Powdermaker's Stranger and Friend: The Way of the Anthropologist. Anthropologists as writers of fiction are discussed by Edward Bruner in the introduction to Anthropology and Literature edited by Paul Benson (1993). Among the most interesting literary texts by anthropologists are Margery Wolf's 'The Hot Spell' written in Taiwan in the late 1950s and published in A Thrice Told Tale (1992), Laura Bohannan's Return to Laughter: An Anthropological Novel (1964) about her fieldwork in Nigeria, and Rhoda Halperin's The Teacup Ministry and Other Stories (2001).

18 Sau-ling Cynthia Wong problematized this mainstream use of minority fiction in the essay 'Autobiography as Guided Chinatown Tour? Maxine Hong Kingston's The Woman Warrior and the Chinese American Autobiographical Controversy' (1992). While Kingston's The Woman Warrior is certainly no straightforward Chinatown tour, earlier writers, including Lin Yutang, Pardee Lowe, and Jade Snow Wong, felt compelled by the fact that they were writing for an almost all-white audience to act as guides to their own ethnic enclaves. 
ethnographic writing (Reed-Danahay 1997: 2). A similarly inclusive meaning of auto-ethnography emerges from the work of Carolyn Ellis and Arthur P. Bochner, who have been promoting self-reflexive writings by social scientists since the 1990s. We may distinguish self-reflexive fiction by ethnographers from fiction by minority writers who engage the legacy of ethnography from the 'object' position, either by assuming the right to represent themselves and their communities, or by returning the ethnographic gaze, or else by deconstructing/displacing ethnographic ways of knowing. I suggest the following provisional typology of genres:

(1) classic ethnography (a scholarly text written by white Americans about non-whites);

(2) native ethnography (a scholarly text written by someone indigenous to the investigated culture);

(3) ethnographic fiction (autobiographical fiction by ethnographers);

(4) minority fiction featuring anthropologists, conceived as a critique of ethnography;

(5) auto-ethnography (minority writings that to some extent fulfill mainstream readers' demand for authentic cultural representations);

(6) counter-ethnography (minority fiction that objectifies mainstream Americans);

(7) mock-ethnography (parodist imitation of ethnography);

(8) anti-ethnography (writings that propose alternatives to ethnographic ways of knowing).

Some texts overlap several categories and no work can be reduced to an exemplar of a category.

All of these genres need to be seen as ways of knowing. Ethnographic ways of knowing are a matter of positioning, not of essential difference. As John Berger argued in Ways of Seeing (1977), what we know - like what we see is always culturally mediated. Positioning needs to be understood as shifting and contextual, though it is usually linked to the way human bodies are interpreted through such cultural categories as race, gender, age, (dis)ability, or sexuality. The 1986 book by Mary Field Belenky et al. titled Women's Ways of Knowing argued that American women, regardless of race and class, relate to knowledge and to themselves as knowers differently than do men (albeit for historical reasons). Poststructuralist feminists problematize this claim while retaining an interest in exploring 'subjugated' ways of knowing - those underrepresented in mainstream literature, the arts, and academia. Feminist critics of science, most prominently Sandra Harding and Donna Haraway, have been seeking a compromise between, on the one hand, the poststructuralist argument that objectivity is a false ideal because all knowledge claims are radically contingent and, on the other, the profound conviction that some knowledges are better (less oppressive, more beneficial to marginalized communities, 
women, the natural environment, etc.) than others. In her 1991 study of the possibilities for instituting a feminist epistemology Harding asked:

Who can be subjects, agents of socially legitimate knowledge? (Only men in the dominant races and classes?) What kinds of tests must beliefs pass in order to be legitimated as knowledge? (Only tests against the dominant group's experiences and observations?) [...] What kinds of things can be known? Can 'historical truths,' socially situated truths, count as knowledge? Should all such situated knowledges count as equally plausible and valid? What is the nature of objectivity? Does it require 'point-of-viewlessness'? [...] Can there be 'disinterested knowledge' in a society that is deeply stratified by gender, race, and class? (1991: 109-110).

It only became possible to ask such epistemological questions recently, when the dominant paradigm of positivist science was challenged by Thomas Kuhn in 1962; when in the 1970s and 1980s Michel Foucault reinterpreted the mechanisms of power upholding emblematic Western institutions and enlightened beliefs; when a critical mass of women and people of color assumed positions of authority. Such questions precipitated the conceptual shift which, in Clifford's words, left social scientists no elevated vantage point "from which to represent the world" (Clifford - Marcus 1986: 22).

Reading Foucault's 1976 lectures on the circulation of power and knowledge, we can reconstruct a compelling story - a seismographic record of events Clifford would later describe as the earth-shaking (Clifford - Marcus 1986). The power of Western institutions, Foucault argued, such as hospitals and prisons, but also academic disciplines, comes from "the production of effective instruments for the formation and accumulation of knowledge - methods of observation, techniques of registration, procedures for investigation and research, apparatuses of control. All this means that power, when it is exercised through these subtle mechanisms, cannot but evolve, organize, and put into circulation a knowledge, or rather apparatuses of knowledge, which are not ideological constructs.” (Foucault 1980: 102) But the hierarchical order of power associated with science is no longer secure, wrote Foucault, for "there is something to which we are witness, and which we might describe as an insurrection of subjugated knowledges" (Foucault 1980: 81, emphasis in the original). Present all along, both inside and outside the knowledge-generating institutions, these upstart knowledges had been systematically disqualified as "inadequate to their task or insufficiently elaborated" (Foucault 1980: 82). Now they are increasingly gaining attention. Some are "erudite knowledges" buried "within the body of functionalist and systematizing theory, which criticism has been able to reveal"; others are "naïve" knowledges, those of the psychiatric patient, prison inmate - and, I would add, of ethnography's 'native informant'. 
Not only are these knowledges particular, local, and differentiated, but they constitute a cacophony of voices "incapable of unanimity" (Foucault 1980: 82). This, however, makes them all the more vital for, unlike the orderly and wellintegrated legitimate discourses, the upstart knowledges (elsewhere called 'anti-sciences') preserve "the memory of hostile encounters which even up to this day have been confined to the margins of knowledge" (Foucault 1980: 83). Antagonism and conflict (as Ernesto Laclau and Chantal Mouffe would later affirm) are catalysts of change, to be heeded not smoothed over. The problem with insurrections, Foucault cautioned in the final part of this story, is that they are all too easily defused. No sooner are these subjugated knowledges "disinterred," "brought to light [...] accredited and put into circulation" than they "run the risk of recodification, re-colonisation" by being integrated into the legitimate knowledges (Foucault 1980: 86).

Foucault's story about the attrition of legitimate and subjugated knowledges resonated with the concerns of feminist poststructuralists who met at conferences, read, and commented on each others' work. Among them were philosophers Sandra Harding, Donna Haraway, and Judith Butler, as well as anthropologists Dorinne Kondo and Lila Abu-Lughod. ${ }^{19}$ "We don't want a theory of innocent powers to represent the world, where language and bodies fall into the bliss of organic symbiosis," wrote Haraway in 'Situated Knowledges' (1988: 579). Refining Foucault's propositions, she insisted that "subjugation is no grounds for an ontology"; there is no unmediated vision from subjugated standpoints, any more than there is from other standpoints (Haraway 1988: 586). Knowers must neither be essentialized nor romanticized, for "the positions of the subjugated are not exempt from critical reexamination, decoding, deconstruction, and interpretation. [...] The standpoints of the subjugated are not 'innocent' positions." (Haraway 1988: 584) Yet that is precisely why, according to Haraway, they should be valorized. Knowing their own knowledges to be marginal, the subjugated are less likely to succumb to the illusion of objectivity or universality (Haraway 1988: 584).

Haraway's own prose straddles philosophy and literature as it conjures up ever new metaphors to break old habits of thought. She also invokes literature as a metaphor for ways of knowing: Native American Coyote tales, Mary Shelley's Frankenstein, and, finally, Katie King's theory of the way "poems" are generated at the intersection of art, business, and technology. The "poem" might very well serve as a model for the kind of non-authoritative, unpretentious, embodied knowledge that Haraway is after:

Like 'poems,' which are the sites of literary production where language too is an actor independent of intentions and authors, 
bodies as objects of knowledge are material-semiotic generative nodes. Their boundaries materialize in social interaction. Boundaries are drawn by mapping practices; 'objects' do not preexist as such. Objects are boundary projects. But boundaries shift from within; boundaries are very tricky. What boundaries provisionally contain remains generative, productive of meanings and bodies. Siting (sighting) boundaries is a risky practice. (Haraway 1988: 595, emphasis in the original)

Many other American academics have sought in the poem, the play, the short story, or the memoir a release from the posture of scientific detachment and objectivity without giving up the pursuit of knowledge. Whereas in the past such breaches of discipline had to be covert (so anthropologists often published literature under pen names) ${ }^{20}$ today they count as innovative scholarship. Writing anthropology, Dorinne Kondo combined the theoretical essay, autobiographical narrative, interview, and play. Other anthropologists, such as Margery Wolf, Edith Turner, and Rhoda Halperin turned their fieldwork experience into short stories. Thus, to use Foucault's vocabulary, we have witnessed a surge of upstart 'erudite knowledges' grounded in the authors' experience deployed as a critique of functionalist and systematizing theory.

Literature rarely makes overt knowledge claims, yet its social and educational function indicates that some readers and educators do see it as mode of knowledge production. Modern nations, as Benedict Anderson (1991) has observed, rely heavily on novels for socializing citizens and building a sense of community. Taught in schools, national literatures are treated as a supplement to history. Taught as part of the American multicultural curriculum, ethnic literatures are an element of civic education. They enter into a dialogue with more legitimate knowledges, and question the ways in which knowledge about non-mainstream groups is produced. It thus seems that what Harding calls 'historical truths' or 'socially situated truths' do count as a form of knowledge when they appear in the form of literature.

One of the ways writers of both literature and ethnography acquire knowledge is through dialogue (or gossip) with others. But the dialogic origins of knowledge are erased in conventional ethnographic texts, while fiction thrives on dialogue. 'Participant observation', the mainstay of ethnography, must be supplemented with gossip - casual conversations with informants about their own private lives and the lives of other members of their small community. One cannot compile kinship charts, reconstruct a community's moral norms, or understand its spirituality without asking personal questions that, under other circumstances, would be considered indiscreet. To highlight

20 The literary pursuits of anthropologists are discussed by John Van Maanen, Tales from the Field (1988); Richard Handler, Critics against Culture: Anthropological Observers of Mass Society (2005: 96-122); and Barbara Tedlock, Works and Wives: On the Sexual Division of Textual Labor (1995). 
this oddity, critic Marianna Torgovnick quotes a memorable passage from Malinowski's introduction to The Sexual Life of Savages, in which he urges the reader to walk with him into a Melanesian village:

We shall follow several [of the villagers] in their love affairs, and in their marriage arrangements; we shall have to pry into their domestic scandals, and to take an indiscreet interest in their intimate life. For all of them were, during a long period, under ethnographic observation, and I obtained much of my material through their confidences, and especially from their mutual scandal-mongering. (Malinowski qtd. in Torgovnick 1990: 3)

Interestingly, this passage suggests that prying and gossiping in the name of science is not only acceptable but that this is what the scientist (and, by extension, the reader) has to do. As the originator of the participant observation method and one of the first anthropologists to spend enough time in the field to comfortably gossip with the 'natives' in their own language, Malinowski must have written this self-reflexive passage out of a need to naturalize his method of securing data. If his successors ever felt a similar discomfort, they could simply ignore it, for by their time the method was well-established in the discipline.

Theorist and filmmaker Trinh T. Minh-ha plainly states her objections to ethnographic ways of knowing and transmitting knowledge about non-Western peoples when she defines them as academically sanctioned gossip. From a postcolonial perspective, she argues, ethnography is not just gossip with the 'natives': it is a conversation among Western academics about people who are conveniently absent and thus unable to talk back. Questioning the assumptions behind passages like Malinowski's above, Trinh points out that:

a conversation of 'us' with 'us' about 'them' is a conversation in which 'them' is silenced. 'Them' always stands on the other side of the hill, naked and speechless, barely present in its absence. Subject of discussion, 'them' is only admitted among 'us,' the discussing subjects, when accompanied or introduced by an 'us,' member, hence the dependency of them and its need to acquire good manners for the membership standing. [...] Anthropology is finally better defined as 'gossip' (we love to speak together about others) than as a 'conversation' (we discuss a question) a definition that goes back to Aristotle. (1989: 67-68)

Ethnographic texts usually erase the specifics of data collecting (except in forewords, introductions, and footnotes) and move directly to exposition and theory. To learn more about the role of gossip in ethnographic research we may 
turn to fieldwork manuals or, better still, to autobiography and fiction by ethnographers. We may look at ethnographic fiction to see how various authors represent the daily practice of gossip as data gathering, and how representation of the practice and product of gossiping changes when the ethnographic subjects are not illiterate members of an isolated Third-World community but English-speaking people who may eventually read what the ethnographer writes.

Although Trinh's dismissal of ethnography as gossip is reductive (it was, of course, intended as a provocation), I do find her trope useful because it draws attention to the relation between subjects, objects, and readers: who is addressing whom and in whose absence/ presence. Reading texts for the 'gossip' factor helps to problematize the faith in creative writing as an alternative to 'realist' ethnography - a way to avoid objectifying, exoticizing, romanticizing, and otherwise exploiting the other. Letting 'the subaltern speak', to use Gayatri Spivak's term, by making ethnographic texts dialogic or polyvocal, or otherwise undermining one's own ethnographic authority, does not necessarily eradicate the asymmetry between observers and observed in terms of control of representation (Spivak 1988).

A century or two ago, literature and ethnography supplemented each other and were not considered qualitatively different ways of knowing. Then, for a time, highbrow literature lost interest in social representation while ethnography cut itself off from literature, the locus of subjectivity and singularity. In Navigators of the Contemporary: Why Ethnography Matters, David A. Westbrook took stock of ethnography' current situation in a world where "the maps have no more blank white spaces; the islands have run out" (2008: 9). He concluded that while there may be no more islands, "there are always margins, and the job of the ethnographer is, now as ever, to report from the margins" wherever they may be in the contemporary world (2008: 10). He asked the anthropologist to think of herself as a "navigator" who needs to triangulate her own position in relation to disparate points in the social geography and in relation to the narratives of her interlocutors (2008: 47). The text she produces

should reflect the situation in question, but it cannot be seen as a mechanical reproduction of the situation, or still less, a mirror of it. In general, ethnography's raw material was not previously available, but instead was the product of negotiation and conversation undertaken by the ethnographer. In important ways, the data cannot be reproduced. One might have a different conversation, later, even involving the same people. Only this navigator, then, was in this position, from which she participated in, observed, analyzed, and reported upon what she saw, that is, the conversations in which she participated and indeed largely staged. Only this navigator could 
say, I was here in social space, at this juncture in various narratives. [...] Thus, rather than a description or representation in the ordinary sense, which is in principle replicable, the expressions of ethnography for present situations are in principle unique. (2008: 64-65)

If Westbrook's voice can be taken as representative, a rapprochement between ethnography and literature is in sight. Much has had to change for ethnographers to be willing to admit that their experience in the field is singular and unique; that cultures can only be accessed through interlocutors who tell stories in response to questions; and that stories are what ethnographers produce when they return from the field. Some ethnographers now understand themselves to be much closer to those fiction writers who have long been 'reporting' from the margins, triangulating their positions in relation to various interlocutors and intertexts, and inventing forms to make sense of the constantly changing social topography. Likewise, literary criticism needs to acknowledge the affinity between ethnography and fiction.

July 2016

\section{Literature}

Anderson, Benedict. 1991. Imagined Communities: Reflections on the Origin and Spread of Nationalism. Revised Edition ed. London and New York: Verso.

Appadurai, Arjun. 1988. Putting Hierarchy in its Place. Cultural Anthropology 3, 1: 36-49.

Attridge, Derek. 2004. The Singularity of Literature. London: Routledge.

Belenky, Mary Field et al. 1986. Women's Ways of Knowing: The Development of Self, Voice, and Mind. New York: Basic Books.

Behar, Ruth. 1996. The Vulnerable Observer: Anthropology That Breaks Your Heart. Boston: Beacon Press.

Benson, Paul (ed.). 1993. Anthropology and Literature. Urbana: University of Illinois Press.

Bentley, Nancy. 1995. The Ethnography of Manners: Hawthorne, James, Wharton. New York: Cambridge University Press.

Berger, John. 1977 [1972]. Ways of Seeing. London: Penguin.

Bernstein, Charles. 1992. A Poetics. Cambridge: Harvard University Press.
Buzard, James. 2003. On AutoEthnographic Authority. Yale Journal of Criticism 16, 1: 61-91.

Capetti, Carla. 1993. Writing Chicago: Modernism, Ethnography, and the Novel. New York: Columbia University Press. Cheung, King-Kok. 2000. Words Matter: Conversations with Asian American Writers. Honolulu: University of Hawaii Press.

Clifford, James. 1986. Introduction. In: Clifford, James - Marcus, George E. (eds.): Writing Culture: The Poetics and Politics of Ethnography. Berkeley: University of California Press: 1-26.

Clifford, James. 1988. Predicament of Culture: Twentieth-Century Ethnography, Literature and Art. Cambridge, Mass.: Harvard University Press. Clifford, James. 1989. The Others: Beyond Salvage Paradigm. Third Text 3, 6: 73-78. Clifford, James. 1997. Routes: Travel and Translation in the Late Twentieth Century. Cambridge, Mass.: Harvard University Press.

Clifford, James - Marcus, George E. (eds.). 1986. Writing Culture: The Poetics and 
Politics of Ethnography. Berkeley: University of California Press.

Culler, Jonathan. 1999. Anderson and the Novel. Diacritics 29, 4: 20-39.

Denning, Greg. 1980. Islands and Beaches: Discourse on a Silent Land, Marquesas 1774-1880. Melbourne: Melbourne University Press.

Edmond, Rod - Smith, Vanessa. 2003. Islands in History and Representation. London: Routledge.

Fabian, Johannes. 1983. Time and the Other: How Anthropology Makes Its Object. New York: Columbia University Press.

Ferens, Dominika. 2002. Edith and Winnifred Eaton: Chinatown Missions and Japanese Romances. Urbana: University of Illinois Press.

Fischer, Michael J. 1986. Ethnicity and the Post-Modern Arts of Memory. In: Clifford, James - Marcus, George E. (eds.): Writing Culture: The Poetics and Politics of Ethnography. Berkeley: University of California Press: 194-233.

Foucault, Michel. 1980. Power/ Knowledge: Selected Interviews and Other Writings 1972-1977. Colin Gordon (ed.). Trans. Colin Gordon et al. Brighton: Harvester Press.

Geertz, Clifford. [1984] 2003. Anti AntiRelativism. In: Darnell, Regna (ed.): American Anthropology 1971-1995: Papers from the American Anthropologist. Lincoln: University of Nebraska Press: 416-439.

Handler, Richard. 2005. Critics against Culture: Anthropological Observers of Mass Society. Maridon: University of Wisconsin Press. Haraway, Donna. 1988. Situated Knowledges: The Science Question in Feminism and the Privilege of Partial Perspective. Feminist Studies 14, 3: 575-599.

Harding, Sandra. 1991. Whose Science? Whose Knowledge? Thinking from Women's Lives. Ithaca: Cornell. Huang, Guiyou - Nelson, Emmanuel

S. (eds.). 2003. Asian American Short Story Writers: An A-to-Z Guide. Westport, CT: Greenwood Press.
Keesing, Felix M. 1958. Cultural Anthropology: The Science of Custom. New York: Rinehart.

Keesing, Roger M. - Keesing, Felix M. 1971. New Perspectives in Cultural Anthropology. New York: Holt.

Kim, Elaine H. 1982. Asian American Literature: An Introduction to the Writings and Their Social Context. Philadelphia: Temple University Press.

Loxley, Diana. 1990. Problematic Shores: Literature of Is/ands. London: Macmillan.

Malinowski, Bronisław. 1984 [1922]. Argonauts of the Western Pacific: An Account of Native Enterprise and Adventure in the Archipelagoes of Melanesian New Guinea. Long Grove, Ill.: Waveland Press.

Marcus, George E. - Fischer, Michael M. J. 1986. Anthropology as Cultural Critique: The Experimental Moment in the Human Sciences. Chicago: University of Chicago Press.

Mead, Margaret. 1973 [1928]. Coming of Age in Samoa: A Psychological Study of Primitive Youth for Western Civilization. New York: Morrow and Co.

Messerschmidt, Donald A. (ed.). 1981. Anthropologists at Home in North America: Methods and Issues in the Study of One's Own Society. Cambridge: Cambridge University Press.

Motzafi-Haller, Pnina. 1997. Writing Birthright: On Native Anthropologists and the Politics of Representation. In: Reed-Danahay, Deborah E. (ed.): Auto/ Ethnography: Rewriting the Self and the Social. Oxford: Berg: 195-222.

Nycz, Ryszard. 2006. Wprowadzenie. Kulturowa natura, słaby profesjonalizm. Kilka uwag o podmiocie poznania literackiego i statusie dyskursu literaturoznawczego. In: Markowski, Michał Paweł - Nycz, Ryszard (eds.): Kulturowa teoria literatury. Główne pojęcia i problemy. Kraków: Universitas.

Palumbo-Liu, David. 1995. Universalisms and Minority Culture. Differences 7, 1: 188-208.

Powdermaker, Hortense. 1966. Stranger and Friend: The Way of an Anthropologist. New York: W.W. Norton and Company. 
Reed-Danahay, Deborah. 1997.

Introduction. In: Reed-Danahay, Deborah

E. (ed.): Auto/Ethnography: Rewriting the Self and the Social. Oxford: Berg: 1-17.

Rose, Dan. 1993. Ethnography as a Form of Life: The Written Word and the Work of the World. In: Benson, Paul (ed.): Anthropology and Literature. Urbana: University of Illinois Press: 192-224.

Spivak, Gayatri Chakravorty. 1988. Can the Subaltern Speak? In: Nelson, Cary - Grossberg, Lawrence (eds.): Marxism and the interpretation of Culture. Chicago: University of Illinois Press: 271-313.

Stocking, George W. 1992. The Ethnographer's Magic and Other Essays in the History of Anthropology. Madison: University of Wisconsin Press.

Tallman, Janet. 2002. The Ethnographic Novel: Finding the Insider's Voice. In: De Angelis, Rose (ed.): Between Anthropology and Literature: Interdisciplinary Discourse. London: Routledge: 11-22.

Tedlock, Barbara. 1995. Works and Wives: On the Sexual Division of Textual Labor. In: Behar, Ruth - Gordon, Deborah A. (eds.): Women Writing Culture. Berkeley: University of California Press: 267-286.

Torgovnick, Marianna. 1990. Gone Primitive: Savage Intellects, Modern Lives. Chicago: University of Chicago Press.
Trinh, T. Minh-Ha. 1989. Woman, Native, Other: Writing Postcoloniality and Feminism. Bloomington: Indiana University Press.

Turner, Edith. 1993. Experience and Poetics in Anthropological Writing. In: Benson, Paul (ed.): Anthropology and Literature. Urbana: University of Illinois Press: 27-47.

Van Maanen, John. 1988. Tales of the Field: On Writing Ethnography. Chicago: University of Chicago Press.

Westbrook, David A. 2008. Navigators of the Contemporary: Why Ethnography Matters. Chicago: University of Chicago Press.

Wolf, Margery. 1992. A Thrice-Told Tale: Feminism, Postmodernism, and Ethnographic Responsibility. Stanford: Stanford University Press.

Wong, Sau-ling Cynthia. 1992. Autobiography as Guided Chinatown Tour? Maxine Hong Kingston's The Woman Warrior and the Chinese American Autobiographical controversy. In: Payne, James Robert (ed.): Multicultural Autobiography: American Lives. Knoxville: University of Tennessee Press: 248-279.

Yu, Henry. 2001. Thinking Orientals: Contact and Exoticism in Modern America. New York: Oxford University Press. 